Canada and the US.

Largely avoiding the debate on acculturation and language loss, Lorenzkowski repeatedly emphasizes the hybrid nature of the German language and culture in Waterloo County and Buffalo. Following several US studies, she argues that particularly in the case of Ontario, a great number of German speakers disagreed with the ethnic leadership and its claims that ethnic identity required the use of non-anglicized, standard German. The author is critical of the ideas that "ethnic gatekeepers" propounded in the German-language press. She describes a tension between two groups in Waterloo County: one that believed that its ethnic identity could be maintained through song, performance, associational life, and memory and another that believed that a supposed widespread Kauderwelsch (gibberish or pidgin German) deteriorated the position of German culture and somehow also threatened to weaken the ethnic identity of the community leaders themselves.

This well-researched book provides innovative answers to a broad set of questions, at the same time making two major historiographical contributions. First, the lens of aural history and the interest in how culture and ethnicity happened is an important shift away from a long-running debate about acculturation and language loss for Germans in Canada. This fresh approach to Canadian ethnic studies will hopefully have a lasting impact on future studies of other immigrant groups. Second, Lorenzkowski's description of the cultural connections across the Ontario-New York border through numerous singers' festivals takes an important step in understanding how transnational connections repeatedly shaped ethnic culture within national and local contexts.

Benjamin Bryce York University.

\title{
Gord Hill, The 500 Years of Resistance Comic Book (Vancouver: Arsenal Pulp Press, 2010).
}

Gord Hill's The 500 Years of Resistance Comic Book is provocative proof that graphic history is an important tool for activists today. In the preface, Hill argues that the dominant narrative of colonial history in the Americas minimizes the story of indigenous resistance, and he maintains that "such a strategy has been used to impose capitalist ideology on people, to pacify them, and to portray their struggle as doomed to failure" (5). To counter this narrative, Hill's work chronicles the long history of indigenous peoples' resistance to colonialism by illustrating the many defeats inflicted on invading European forces and highlighting the strength of contemporary indigenous resistance movements from Chiapas to New Caledonia. Indeed, the very purpose of The 500 Years of Resistance Comic 
Book is to "raise levels of historical understanding [about resistance and] warrior spirit among Indigenous peoples and others" (6). Hill showcases the dialectical relationship between colonial abuses and ongoing indigenous resistance, and, in doing so, makes an important contribution to the literature examining the colonial past.

Hill situates the history of indigenous resistance to colonialism and capitalism in a global context. He begins by recounting the events of the "1492 invasion" and how Columbus sought to conquer, Christianize, and enslave the hospitable Tainos while creating the first European colony in the Americas, La Navidad. Hill explains that when Columbus returned to the colony in 1493 he found it destroyed "after the Taino retaliated against rapes and murders carried out by the Spaniards" (28). Hill uses this example to set the tone as well as to show how European colonization unleashed a new "reign of terror and death" to acquire "gold, silver, wood and food crops" (31). Hill maintains, though, that the "colonization of the Americas... was not easy. It involved centuries of war as our ancestors fought a life and death struggle" (37). Hill then outlines the details of a variety of different indigenous resistance movements from Inca and Aztec opposition, to the Pontiac Rebellion in 1763, the Battle of Little Big Horn, and the Battle of Wounded Knee in 1890. Instead of ending here, Hill shows how overt colonial brutality turned into bureaucratic violence and policies of assimilation: "a common strategy of colonial regimes is to assimilate surviving native peoples into the colonial society...This makes the native easier to control as well as an obedient worker and consumer" (61). The goal of such policies, Hill makes clear, is "to destroy all indigenous culture and identity that inspires our spirit of resistance, and which limits their plans of exploitation" (62). In the second half of the twentieth century, Hill explains how indigenous peoples, inspired by the civil rights movement and global decolonization struggles, renewed resistance tactics resulting in such actions as the occupations of Alcatraz in 1969 and Wounded Knee in 1973, the Oka conflict in 1990, the Zapatista uprising in 1994, and the Six Nations confrontation with Ontario police in 2006. Hill brings these diverse events together creating an impressive picture of widespread destruction and, simultaneously, impassioned and ongoing resistance.

Of course, what separates Hill's treatment of the history of indigenous resistance in the Americas is his use of the graphic history format. The 500 Years of Resistance Comic Book mixes historical research, primary source materialincluding quotes and renditions of historical photographs - with sharp narration and graphic illustrations. Despite the popularity of graphic histories by Chester Brown (Louis Riel) and even Howard Zinn (A People's History of American Empire), many scholars continue to dismiss the graphic history format. When asked to write the introduction to Hill's comic book, Ward Churchill was admittedly skeptical; however, the "sophistication and communicative effectiveness" of Hill's work quickly "transformed" Churchill's appreciation for the graphic approach to 
history (7). Indeed, the graphic format has much to offer activists today. In Hill's words: "The strength of the comic book is that it uses minimal text with graphic art to tell the story. This format is useful for reaching children, youth, and adults who have a hard time reading books or lengthy articles. We may use many diverse methods of communication-including newsletters, books, videos, music, posters, stickers, paintings, banners, and T-shirts-because no simple one will be successful by itself" (6). There are, of course, limitations to the graphic medium and to Hill's work specifically. For example, Hill chooses to exclude the important political movements fighting for land and dignity through legal channels. One reason for this choice could be that the logistics of legal battles do not lend themselves as easily to the graphic artist as do the events of blockades and occupations. Nevertheless, Hill's work could have also discussed such tactics and strategies to render a more nuanced picture of ongoing indigenous resistance to colonialism.

The 500 Years of Resistance Comic Book is both an important contribution to the literature on colonialism in the Americas and a major intervention in the emerging field of activist graphic history. In our struggles to renew activist energy for the twenty-first century, we must embrace graphic histories, like Hill's comic book, as significant tools that can help inspire people's critical engagement with the past and present.

Sean Carleton

Trent University

\section{Ian Hesketh, The Science of History in Victorian Britain (London: Pickering \& Chatto, 2011).}

This is a book about how Victorians wrote history and the struggle within the discipline in determining history's appropriate subject matter, methodology, and boundaries. Intellectual historian Ian Hesketh uncovers a surprisingly complex conflict in the professionalisation of history. He does this by presenting material gleaned from diverse sources including public lectures and obituaries. At the heart of this conflict is the question of whether history is an art or a science. Through extensive research, the author reveals a much more multifaceted struggle than traditionally perceived in a somewhat aggressive pursuit to make history a science.

In this detailed analysis, Hesketh depicts an ongoing battle to establish the proper domain and method of history through the examination of the lectures and letters of renowned historians. Henry Thomas Buckle is presented as a champion of the scientific method with a soft side for the artistic component. The more hardcore proponents of an inductive method of science include 